INTERNATIONAL DESIGN CONFERENCE - DESIGN 2018

https://doi.org/10.21278/idc.2018.0107

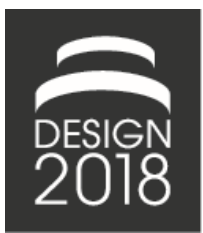

\title{
REFLECTING ON THE EMPLOYABILITY ADEQUACY OF COMPETENCIES TAUGHT IN DESIGN HIGH EDUCATION SYSTEM
}

\author{
R. A. Almendra and G. A. Falcão
}

\begin{abstract}
This paper exposes a clear reflection about design competencies, addressing the ones academia finds necessary to be acquired by design students and the ones the market requires from designers. Besides the identification of those competencies an analysis is done considering the similarities and the differences between these two "worlds." Finally, the paper proposes a set of recommendations on how to work into education a set of competencies that better match the needs both students/designers and the markets.
\end{abstract}

Keywords: design education, design competences, design knowledge, employability competences, knowledge sharing

\section{Introduction}

Education in Europe began with the foundation of schools, and evolved into the model of the medieval university first formalized in Bologne in 1088. That model continued to develop into the 20th century, a noteworthy period in which the Higher Education system became available to more than just elites, i.e. education was democratized. Currently, the EU aims to achieve a $40 \%$ student graduation rate by 2020 (European Commission, 2013, p. 12). This ambition is related to the efforts being made to affirm the Europe of Knowledge, one more modernized and better suited to face the challenges of a globalized word, in constant change and with significant social, geo-political, economic and environmental problems. As a way of fulfilling its goals within the EU, which brings together different countries with diverse social, cultural, economic and political systems, it was decided in 1998 (Sorbonne Declaration) to find a way of standardizing the System of Higher Education, making it equivalent in terms of degrees and diplomas among all countries. In 1999 the declaration of Bologne was born, establishing goals for student mobility as a way to accelerate the sharing of knowledge, foment research, and to promote greater and better integration of students in the market. It also established itself as a pillar of this Europe of Knowledge and lifelong learning, which will make it possible to fight unemployment, raise the skills of the labour force and facilitate the promotion of social inclusion. Furthermore, it will allow a holistic knowledge as we learn how to learn and to develop knowledge in a continuous way (Tedesco, 2008). To understand how in general Higher education systems are working competences and the way it serves or not the markets (in southern societies) is one of the aims of the reflection we make in this paper. This is central so one can rethink programs curricula and the courses to be taught. To do so it is important to understand the Europe of Knowledge context; the role of research in design education; the model of design education that better suits societies' need - generalist vs specialized and finally to have a view on the competences being worked by education systems and the ones the markets aspire to contract. 


\section{The Europe of Knowledge context}

To guarantee the affirmation of a Europe of Knowledge “(...) European graduates need an education that enables them to work together in a coherent way as global citizens, committed and active, thinkers as well as economic agents in the ethical and sustainable development of our societies" (European Commission, 2013).

To achieve this desideratum, Europe had to introduce a mechanism that would allow analysis of the qualifications of its nations, to create an equivalence of certificates and diplomas. This mechanism is the European Qualifications Framework (EQF), a system that integrates eight European levels of reference, allowing, through the description of the nature of knowledge, skills to be acquired and their associated abilities, to compare the different qualification systems of European countries. The EQF was adopted in 2008, and after determining the types of qualifications and their relative value for each country, national qualification matrixes were created, the so-called NQF (national qualifications framework).

Table 1. European Qualifications Framework (EU website)

\begin{tabular}{|c|c|c|c|}
\hline EQF & Knowledge & Skills & Competence \\
\hline & $\begin{array}{l}\text { In the context of EQF, } \\
\text { knowledge is described as } \\
\text { theoretical and/or factual. }\end{array}$ & $\begin{array}{l}\text { In the context of EQF, skills are } \\
\text { described as cognitive (involving } \\
\text { the use of logical, intuitive and } \\
\text { creative thinking), and practical } \\
\text { (involving manual dexterity and } \\
\text { the use of methods, materials, } \\
\text { tools and instruments) }\end{array}$ & $\begin{array}{l}\text { In the context of EQF, } \\
\text { competence is described in } \\
\text { terms of responsibility and } \\
\text { autonomy. }\end{array}$ \\
\hline Level 1 & Basic general knowledge & $\begin{array}{l}\text { Basic skills required to carry out } \\
\text { simple tasks }\end{array}$ & $\begin{array}{l}\text { Work or study under direct } \\
\text { supervision in a structured } \\
\text { context }\end{array}$ \\
\hline Level 2 & $\begin{array}{l}\text { Basic factual knowledge of a } \\
\text { field of work or study }\end{array}$ & $\begin{array}{l}\text { Basic cognitive and practical } \\
\text { skills required to use relevant } \\
\text { information to carry out tasks } \\
\text { and to solve routine problems } \\
\text { using simple rules and tools }\end{array}$ & $\begin{array}{l}\text { Work or study under } \\
\text { supervision with some } \\
\text { autonomy }\end{array}$ \\
\hline Level 3 & $\begin{array}{l}\text { Knowledge of facts, } \\
\text { principles, processes and } \\
\text { general concepts, in a field of } \\
\text { work or study }\end{array}$ & $\begin{array}{l}\text { A range of cognitive and } \\
\text { practical skills required to } \\
\text { accomplish tasks and solve } \\
\text { problems by selecting and } \\
\text { applying basic methods, tools, } \\
\text { materials and information } \\
\end{array}$ & $\begin{array}{l}\text { Take responsibility for } \\
\text { completion of tasks in work or } \\
\text { study, adapt own behaviour to } \\
\text { circumstances in solving } \\
\text { problems }\end{array}$ \\
\hline Level 4 & $\begin{array}{l}\text { Factual and theoretical } \\
\text { knowledge in broad contexts } \\
\text { within a field of work or } \\
\text { study }\end{array}$ & $\begin{array}{l}\text { A range of cognitive and } \\
\text { practical skills required to } \\
\text { generate solutions to specific } \\
\text { problems in a field of work or } \\
\text { study }\end{array}$ & $\begin{array}{l}\text { Exercise self-management } \\
\text { within the guidelines of work } \\
\text { or study contexts that are } \\
\text { usually predictable, but are } \\
\text { subject to change; supervise } \\
\text { the routine work of others, } \\
\text { taking some responsibility for } \\
\text { the evaluation and } \\
\text { improvement of work or study } \\
\text { activities }\end{array}$ \\
\hline $\begin{array}{l}\text { Level } \\
5[1]\end{array}$ & $\begin{array}{l}\text { Comprehensive, specialised, } \\
\text { factual and theoretical } \\
\text { knowledge within a field of } \\
\text { work or study and an } \\
\text { awareness of the boundaries } \\
\text { of that knowledge }\end{array}$ & $\begin{array}{l}\text { A comprehensive range of } \\
\text { cognitive and practical skills } \\
\text { required to develop creative } \\
\text { solutions to abstract problem. }\end{array}$ & $\begin{array}{l}\text { Exercise management and } \\
\text { supervision in contexts of work } \\
\text { or study activities where there } \\
\text { is unpredictable change, } \\
\text { review and develop } \\
\text { performance of self and others }\end{array}$ \\
\hline
\end{tabular}




\begin{tabular}{|l|l|l|l|}
\hline $\begin{array}{l}\text { Level } \\
6[2]\end{array}$ & $\begin{array}{l}\text { Advanced knowledge of a } \\
\text { field of work or study, } \\
\text { involving a critical } \\
\text { understanding of theories } \\
\text { and principles }\end{array}$ & $\begin{array}{l}\text { Advanced skills, demonstrating } \\
\text { mastery and innovation, required } \\
\text { to solve complex and } \\
\text { unpredictable problems in a } \\
\text { specialized field of work or } \\
\text { study }\end{array}$ & $\begin{array}{l}\text { Manage complex technical or } \\
\text { professional activities or } \\
\text { projects, taking responsibility } \\
\text { for decision-making in } \\
\text { unpredictable work or study } \\
\text { contexts; take responsibility } \\
\text { for managing professional } \\
\text { development of individuals } \\
\text { and groups }\end{array}$ \\
\hline $\begin{array}{l}\text { Level } \\
7[3]\end{array}$ & $\begin{array}{l}\text { Highly specialized } \\
\text { knowledge, some of which is } \\
\text { at the forefront of knowledge } \\
\text { in a field of work or study, as } \\
\text { the basis for original } \\
\text { thinking and/or research }\end{array}$ & $\begin{array}{l}\text { Specialized problem-solving } \\
\text { skills required in research and/or } \\
\text { knovation to develop new } \\
\text { to integrate knowledge from } \\
\text { different fields }\end{array}$ & $\begin{array}{l}\text { Manage and transform work or } \\
\text { study contexts that are } \\
\text { complex, unpredictable and } \\
\text { require new strategic } \\
\text { approaches, take responsibility } \\
\text { for contributing to professional } \\
\text { knowledge and practice and/or } \\
\text { for reviewing the strategic } \\
\text { performance of teams }\end{array}$ \\
\hline $\begin{array}{l}\text { Level } \\
8[4]\end{array}$ & $\begin{array}{l}\text { Critical awareness of } \\
\text { knowledge issues in a field } \\
\text { and at the interface between } \\
\text { different fields } \\
\text { Knowledge at the most } \\
\text { advanced frontier of a field } \\
\text { of work or study and at the } \\
\text { interface between fields }\end{array}$ & $\begin{array}{l}\text { The most advanced and } \\
\text { specialized skills and techniques, } \\
\text { including synthesis and } \\
\text { evaluation, required to solve } \\
\text { critical problems in research } \\
\text { and/or innovation and to extend } \\
\text { and redefine existing knowledge } \\
\text { or professional practice }\end{array}$ & $\begin{array}{l}\text { Demonstrate substantial } \\
\text { authority, innovation, } \\
\text { autonomy, scholarly and } \\
\text { professional integrity and } \\
\text { sustained commitment to the } \\
\text { development of new ideas or } \\
\text { processes at the forefront of } \\
\text { work or study contexts } \\
\text { including research }\end{array}$ \\
\hline
\end{tabular}

SOURCE (EU website (European Commission, n.d.))

Notes: Compatibility with the Framework for Qualifications of the European Higher Education Area The Framework for Qualifications of the European Higher Education Area provides descriptors for cycles. Each cycle descriptor offers a generic statement of typical expectations of achievement and abilities associated with qualifications that represent the end of that cycle.

The descriptor for the higher education short cycle (within or linked to the first cycle), developed by the Joint Quality Initiative as part of the Bologna process, corresponds to the learning outcomes for EQF level 5.

The descriptor for the first cycle in the Framework for Qualifications of the European Higher Education Area corresponds to the learning outcomes for EQF level 6.

The descriptor for the second cycle in the Framework for Qualifications of the European Higher Education Area corresponds to the learning outcomes for EQF level 7.

The descriptor for the third cycle in the Framework for Qualifications of the European Higher Education Area corresponds to the learning outcomes for EQF level 8.

However, this matrix resulted in a higher education system organised into three cycles - 3 of graduation; 2 of master (or 4+1 integrated master) and 3 to $5 \mathrm{PhD}$-, implying, as mentioned by Bianchetti (2010), a totally different academic organization, since the demand for reflection on the context of the real world is more acute and the proposed teaching model was for a shorter period of time.

Thus, the challenge is to train future practitioners in less time to have a heightened ability to reflect and act. This task is facilitated by the impressive development of information technologies that makes it easier to exchange information and facilitates communication among individuals, allowing them to share and exchange knowledge (Gouveia, 2003). Also, a reliance on life-long learning works as a method to fill this gap, allowing the time for acquisition and generation of knowledge to be lengthened. Tedesco (2008) advocates that in this context, the acquisition of knowledge and competences must be based on education that foments cultural openness and that works within the social consciousness, enlarging the goals of student's qualifications beyond the academic, toward fulfilment of social goals. 
This expanded training presupposes that students will acquire relational competences that sustain a better dialogue and co-construction of knowledge benefiting societal development. Therefore, it is important to consider the vision of Dias et al. (2016), who suggest the necessity of creating, at the Higher Education level, and particularly in design education, interdisciplinary environments adjusted to learning based on problems and its quest as well as in critical assessment adjusted to the development of knowledge share nets.

\section{The role of research in design education and its implications in the design of competences}

Today, it is impossible to educate designers without teaching them how to do research. In fact, the research process has several similarities to the design process. Currently it is fundamental to create a research culture in academia, one that supports students in their search for information and knowledge and their ability to think, connect and transform data. Still, research on education, stimulating continuous pedagogical critiques and reviews, that proposes alternatives to the current problem/solution model might include the research of problems and posing questions to address problems.

Moreover, the deepening of a research culture focused on social and political themes might allow students to operate in a much better defined and informed social context.

The fact is that this in-depth integration of research in design education has defined and determined the acquisition of several competences related to the specificity of the area that also facilitate matching what the market search as competences of their future employees - ability to deal with complex information and problems, good assessment of context and a key use of tools to capture behaviour, anticipate future scenarios, promote resilience, dialogue with different stakeholders.

\section{Discussing vocational design training focusing on markets}

In the Design field, education and training must enhance the multi-interdisciplinarity that characterizes practices in the field. Thus, it is necessary to establish a relationship between different fields of knowledge in order to be able to frame and develop a process aimed at finding solutions to societal problems. In so doing, one aims at educating practitioners that are autonomous and flexible, and have good capacity for self-learning, that are resilient and have a spirit of cooperation and entrepreneurship. (Jacquinot, 1993).

The goal of educating designers is not simply the creation of manpower but instead, and most importantly, teaching young people to think like designers, independent of the place and function they exercise (municipality managers; director of food chain, etc.) The intent is for their practices to benefit from the design thought process (heavily supported by adductive reasoning (Peirce concept), that is, hypothesis formulation before a situation's confirmation or denial) allowing them to exercise their competences of empathy, design, problem-solving and communication, independently of the context.

Thus we agree with Gunnar Swanson (1997), in this case reflecting upon the field of graphic design, who over 20 years ago (the original text was printed in 1994), at a time in which the market had the ability to absorb the majority of design students, said: 'in light of this tendency toward professionalism, it may seem counterintuitive that I suggest that we not only increase the augmentation of design training with more liberal studies, but also reconsider graphic design education as a liberal arts subject (...) On the whole, design schooling has not helped students become broader thinking people who can help shape a democratic society. (...) The tools of graphic design do not seem too much of a purpose beyond a graphic design career. Graphic design education is not, for the most part, educational, it is vocational training, and rather narrow specialized training at that.". Nevertheless, it is still an issue if one should engage in a more specialized or generalized design education model since both in depth and holist transdisciplinary knowledge is required for the designer of the XXI century to meet the complexity and intensity of the world he/she integrates.

\section{Generalist or specialist education - which competences to work with?}

The Gabe and Abel (2012) study demonstrates that there are clear geographical tendencies in terms of competences and that specialized knowledge tends to be concentrated in big cities. It also reveals that 
employment that requires a more generic knowledge is much more common than employment that requires very specialized knowledge.

On the other hand, the study by Bacolod et al. (2009) analyses the role of "soft skills" and their concentration in cities and industries, revealing that those competences facilitate more productive interactions once the most successful employees show themselves to have them.

Also, Guthrie, in a 2009 study with PhD students in education, professional practice and research in education, discovered that although their programs develop different competences, they could find jobs in different areas since employers do not have a specialized knowledge about their specific competences, focusing instead on generalist ones. In the Design education field most of the soft skills are already being pedagogically addressed since the nature of the discipline implies that practitioners engage in multidisciplinary teams. Nonetheless, in this 21 st century the interpersonal and intrapersonal competencies have become much more important than in the past.

\section{An overview of the competences should students have when they enter the job market}

According to Dzib Goodin (2012), there are two worlds, the academic world, which proposes that certain competences are important for students to find their way in the labour market, and the world of business, which is focused on creating jobs, keeping them, making money and creating prosperity for communities and countries.

Some people remain between these two worlds but most choose one or the other. Students are necessarily in between and that is why it is so important that they know how to select and manage information and solve problems, and that they possess metacognitive competences. The problem is that in Higher Education, course contents are named for scientific areas and not for competences that are assumed as the course goals.

Table 2 (Dzib Goodin 2012) presents the differences between what companies consider to be the necessary competences and what academia highlights as important.

Table 2. Differences between academic competences and business competences

\begin{tabular}{|c|c|c|c|}
\hline Academic Competences & Academic attitudes & Work competences & $\begin{array}{l}\text { Work and personal } \\
\text { attitudes }\end{array}$ \\
\hline $\begin{array}{l}\text { Oral and written } \\
\text { communication }\end{array}$ & Good presentations & $\begin{array}{l}\text { Oral and written } \\
\text { communication }\end{array}$ & Self-esteem \\
\hline Solving problems & $\begin{array}{l}\text { Work under teacher's } \\
\text { pressure }\end{array}$ & Solving problems & $\begin{array}{l}\text { Work under the pressure } \\
\text { of lines of command }\end{array}$ \\
\hline Metacognitive & Promote learning & Metacognitive & Promote problem solving \\
\hline Time management & $\begin{array}{l}\text { Plan and finish tasks on } \\
\text { time }\end{array}$ & Time management & $\begin{array}{l}\text { Prioritize tasks and work } \\
\text { on different projects at } \\
\text { the same time, use work } \\
\text { time wisely. }\end{array}$ \\
\hline Technological & $\begin{array}{l}\text { Good management of } \\
\text { new technologies }\end{array}$ & Technological & $\begin{array}{l}\text { Superior management of } \\
\text { new technologies }\end{array}$ \\
\hline $\begin{array}{l}\text { Leadership and group } \\
\text { management }\end{array}$ & Achieve joint goals & $\begin{array}{l}\text { Leadership and group } \\
\text { management }\end{array}$ & $\begin{array}{l}\text { Achieve goals and work } \\
\text { jointly or independently } \\
\text { of people }\end{array}$ \\
\hline
\end{tabular}

An analysis of Table 2 shows that there are competences common to both worlds but at different levels and with different goals. As an example, Dzib Goodin (2012) states "Time management abilities can be a challenge for students with 5 or 7 professors requiring tasks at the same time. The main difference will be a professor always saying exactly how and when they want things. There is no opportunity for a high level of solving problems.'”.

Table 3 (Dzib Goodin, 2012) presents another group of competences and, in this table, there are clear divergences between the two worlds. 
Table 3. Differences between academic competences and business competences (divergent ones)

\section{ACADEMIC COMPETENCIES}

Theoretical and practical knowledge and its application in specific disciplines

Ability and will to share his/her point of view with school

Development of social networks

Resilience

Presentation

Leadership and group management

\section{ACADEMIC} ATTITUDES

Answer how and when is needed

Loyalty to institution

Excel in groups

Acceptance of criticisms

Effective attitude while explaining concepts or theories

The group is important but the grade is more important

\section{WORK COMPETENCIES}

Ethics in work

Ability to solve group and not only personal problems

Act as part of a group

Ability to accept and learn from criticisms Communication ability allowing harmonious relationship between employees and clients Initiative and competence to embrace new projects

\section{PERSONAL AND} WORK ATTITUDES

Positive attitude; enthusiasm

Flexibility and

Adaptability

Loyalty

Honesty and integrity

Common sense and

sense of humour

Creativity in all senses

Source: (Dzib Goodin, 2012)

Table 3 shows a clear maladjustment in the views of both sides. For instance, common sense and sense of humour are not in the academic agenda. The ability to deal with a myriad of different people in the markets is vital to progress and keep a job, but that competence is not specifically sought in academia. On the other hand, what students know in the academic field is related to how it will be evaluated, limiting the knowledge to controlled situations, which is not at all the case in companies now.

Furthermore, one can perceive the same type of divergences in the study by Blaxell and Moore (2012) which proposed to compare competences and attributes employers find desirable and those traditionally required to obtain academic 'success'. In truth, the authors conclude that both sets of competences have several similarities, being supported by the same principles. Thus, they argue that it is possible to design learning experiences supporting the development of those competences, and to integrate these experiences into the contents of the programs of specific academic courses. The proposal is to focus on the simultaneous development of academic attributes and competences as well as 'employability', since they are not antagonistic, being based on the same principles and thus possible to connect efficiently.

The DEST report about employability competences (2002,quoted by Blaxell and Moore, 2012) identifies the personal qualities that are important to employers such as: loyalty, commitment, honesty and integrity, reliability, enthusiasm, personal presentation, common sense, positive self-esteem, sense of humour, balanced attitude between work and personal life, ability to deal with pressure, resilience and motivation. These attributes and competences cannot be taught in isolation and require a commitment to reflection and thought on the part of both teachers and students. It is also necessary that what Blaxell and Moore (2012) call 'self-efficacity' take place on both sides, i.e. the ability to believe in one's own abilities so they can activate them.

On the other hand, and seen from the student perspective, in the study of Miles et al. (2002) we find that there are seven habits common to successful students. They are: passion (alignment of personal interests with study requirements resulting in energy and motivation); construction of support and relationship networks; questioning (pose questions, being inquisitive), being organized and a good time manager; being strategic and an effective manager of resources, keeping the balance between work and personal life and being committed to her/his goals. This type of attitude facing work and life in general, although dependent on personality, might and should be stimulated by Education. Regarding this, Table 4 developed by Blaxell and Moore (2012) exposes the existing links between academic competences and employability ones. 
Table 4. Links between key employability skills and academic skills

Employability skills

Formal communication (multiliteracy) including:

writing to the needs of the audience

using numeracy

speaking in a public forum and

understanding the needs of internal and external

customers

using computer technology appropriately and

staying familiar with up-to-date equipment, facilities and materials

Interpersonal and teamwork skills, including ability and willingness to engage with diverse cultures by: communicating respectfully (using voice and body)

listening actively

empathizing

persuading effectively and

being assertive and

establishing and using networks

collaborating with others to achieve team goals

recognizing and adopting roles within teams

giving and receiving feedback

coaching and mentoring and

leading with integrity

Theoretical and practical knowledge and experience of industry demonstrated by:

recognizing and enacting of company specific skills

gaining experience and participating in work related activities;

having sound knowledge of industry specific content understanding business processes- inclusive of aspects such as customer service.

Intrapersonal skills, including ability and willingness to contribute to productive outcomes by:

identifying opportunities

generating a range of options

initiating innovative solutions

translating ideas into action

adapting to new situations

maintaining sense of humour and positive self-esteem

under pressure

being open to new ideas and techniques

evaluating and monitoring own performance

taking responsibility

managing own learning and

aligning work and learning with personal vision and goals

High level planning and organizing skills demonstrated by:

planning and managing workloads efficiently
Academic skills

Formal communication at a tertiary level

(multiliteracy) including:

academic writing

effectively using numeracy skills to complete

assignments and other tasks

completing oral presentations/ reports for internal or external audiences and

critically reading and engaging with texts

communicate and complete given tasks effectively and enhance engagement with university activities

Interpersonal and teamwork skills, including ability and willingness to engage with diverse cultures by: communicating respectfully (using voice and body)

listening actively

empathizing

persuading effectively

establishing and

using networks within the university

and establishing external community and industry

networks

collaborating with others to achieve team goals

recognizing and adopting roles within teams

giving and receiving feedback and

committing to a team for the period required to complete the task

Theoretical and practical knowledge and experience of discipline demonstrated by applying discipline specific knowledge:

in authentic contexts

for authentic purposes

in discipline-related activities

for academic assessments and

while engaging in WIL

Intrapersonal skills, including ability and willingness to align university engagement with personal vision and goals by:

identifying opportunities

generating a range of options

initiating innovative solutions

translating ideas into action

adapting to new situations

maintaining sense of humour and positive self-esteem

under pressure

being open to new ideas and techniques

self-assessment

taking responsibility and

managing own learning 
allocating time and resources effectively establishing clear goals and plans of action

Problem solving, independent and innovative thinking skills, demonstrated by: engaging in logical and orderly thinking willingly and proactively making decisions identifying opportunities not immediately obvious to others

\author{
High level planning and organising skills \\ demonstrated by effective day-to-day and longer \\ term: \\ planning and management of workloads \\ allocating of time and resources and \\ prioritising tasks according to personal goals
}

Problem solving, independent and innovative thinking skills, demonstrated by:

conducting and completing research

engaging in logical and orderly thinking

willingly and proactively making decisions

identifying opportunities not immediately obvious to others creating innovative solutions to given problems and accurately analysing and synthesising information

Source: Blaxell and Moore (2012, p. 5)

Contributing to this topic, researchers Holtzman and Kraft (2011) sought to compare the feedback between graduates and employers in relation to the necessary competences to work in the 21 st century, and they found that both placed the following as the top, most important priorities: time management; communication/orality and interpersonal competences. They also identify among the employers that holistic knowledge on global issues is currently one of the most important competences to work. An indepth look at the five competences most relevant to employers, one sees that besides interpersonal competences and time management (which obtained 100\%) and the ability to communicate/orality/speech (which had 98\%), ethical comprehension has a weight of $98 \%$ and the ability to adapt/change/be flexible is valued at $96 \%$. As for the graduates, in addition to the competences they have in common with employers, they identified critical and analytical thinking, and the ability to locate, organize and evaluate relevant information as being the remaining competences for their top five. This gap between visions give us some clues in terms of the work to be done to match these two visions. We must consider that in this case we are talking about graduates and not students, meaning people that are already employed.

In 2006 and 2007, the company Peter D. Hart Associates, Inc., selected by the Association of American Colleges and Universities (AACU, 2008), made a qualitative and quantitative evaluation on the points of view of employers regarding the competences offered by the Higher Education System. The study's first phase included 305 interviews of employers with more than 25 employees, reporting $25 \%$ new workers holding at least a graduate degree. In 2007, 301 more interviews were conducted. Table 5 shows the results regarding the areas of competences employers wish were better addressed and taken on by universities.

\section{Table 5. Skills and areas of knowledge a majority of employers would like colleges} and universities to emphasize more

\begin{tabular}{|c|c|c|c|}
\hline $\begin{array}{l}\text { Concepts and new developments in science } \\
\text { and technology. }\end{array}$ & $82 \%$ & $\begin{array}{l}\text { Teamwork skills and the ability to } \\
\text { collaborate with others in diverse group } \\
\text { settings }\end{array}$ & $76 \%$ \\
\hline $\begin{array}{l}\text { The ability to apply knowledge and skills to } \\
\text { real-world settings through internships or } \\
\text { other hands-on experience }\end{array}$ & $73 \%$ & $\begin{array}{l}\text { The ability to effectively communicate } \\
\text { orally and in writing }\end{array}$ & $73 \%$ \\
\hline $\begin{array}{l}\text { Critical thinking and analytical reasoning } \\
\text { skills }\end{array}$ & $73 \%$ & $\begin{array}{l}\text { Global issues and developments and their } \\
\text { implications for the future }\end{array}$ & $72 \%$ \\
\hline $\begin{array}{l}\text { The ability to locate, organize, and evaluate } \\
\text { information from multiple sources }\end{array}$ & $70 \%$ & $\begin{array}{l}\text { The ability to be innovative and think } \\
\text { creatively }\end{array}$ & $70 \%$ \\
\hline The ability to solve complex problems & $64 \%$ & $\begin{array}{l}\text { The ability to work with numbers and } \\
\text { understand statistics }\end{array}$ & $60 \%$ \\
\hline A sense of integrity and ethics & $56 \%$ & $\begin{array}{l}\text { Cultural values and traditions in America } \\
\text { and other countries }\end{array}$ & $53 \%$ \\
\hline
\end{tabular}

Source: (adapted from AACU, 2008) 
Although for 9 nine years AACU has been presenting different priorities in respect to competences, as compared with the other studies presented (most probably because it is a broad study surveying a huge variety of scientific areas and not focused on a specific one), once again one may be confronted with employer's desires and this data should be carefully interpreted by academia.

\section{Some recommendations for matching of academic and employability competences in Design Education}

If "knowledge and competences acquisition must be accompanied by the education of character, of cultural openness and an increase in social responsibility" (Tedesco, 2008, p. 60), Design Education must work on this behaviour early in the process, i.e. in the pre-university education system. Thus, a much clearer and more consistent relationship between the higher education system and High School is required. Tedesco (2008) also suggests that only with knowledge instruction one can promote the change of the social paradigm based on people's knowledge, information and intelligence. This reinforces the idea that academia plays a fundamental role in citizenship and character formation and that it is through education that one can train people for deeper analyses of the reasons behind problems instead of focusing on solutions. This has to do with the so called "deeper learning" that Pellegrino and Hilton, $(2012$, p. 5) defined has "the process through which an individual becomes capable of taking what was learned in one situation and applying it to new situations". To achieve this academia should stimulate creativity and curiosity instead of obedience and memory, as often happens. Thus, students should have competencies associated with metacognition as proposed by Hattie (2012) and Fullan and Langworthy (2014) or like (Tedesco, 2008, p. 59) proposes they should have "knowledge and competences more broad than deep, they should be able to learn how to learn and be convinced of the necessity to continuously develop their level of knowledge". This way they will succeed as higher education students, but more importantly as citizens with minds of their own, able to take their own decisions. This citizenship ability corresponds to most of the aims of the market since the market is a complex system of agents that depend heavily on the activation of social and humanistic abilities namely collaboration ability that requires the ability to "work in teams, learn from and contribute to the learning of others, (use) social networking skills, (and demonstrate) empathy in working with diverse others (Fullan, 2013, p. 9). Moreover, it is recommended that universities begin to visibly incorporate employability competences into their course contents, increasing student's awareness and devising strategies for more internship training, exposing students to these ideas while designing portfolios and materials for the students to break into markets, to test them in the real world, promoting joint sessions between graduating students and employers, to design specific material to identify generic competences, specific competencies and employability competencies for teachers, staff and students. Finally, we must embrace continuous contact among teachers, alumni and students, with the focus of reflecting on the attributes and competences deemed most important and how to master them.

\section{References}

AACU (2008), College learning for the new global century: Executive summary with employers' view on learning outcomes and assessment approaches. [online] Association of American Colleges and Universities. Available at: https://www.aacu.org/leap/documents/GlobalCentury_ExecSum_3.pdf

Bacolod, M., Blum, B.S. and Strange, W.C. (2009), "Urban interactions: soft skills versus specialization”, Journal of Economic Geography, Vol. 9 No. 2, pp. 227-262. https://doi.org/10.1093/jeg/lbn057

Bianchetti, L. (2010), "O Processo de Bolonha e a intensificação do trabalho na universidade: entrevista com Josep M. Blanch”, Educação \& Sociedade, Vol. 31, No. 110, pp. 263-285. http://doi.org/10.1590/S010173302010000100014

Blaxell, R. and Moore, C. (2012), “Connecting academic and employability skills and attributes. In Developing student skills for the next decade", Proceedings of the 21st Annual Teaching Learning Forum, February 2-3 2012, Murdoch University, Perth.

Dias, A.C., Almendra, R. and Moreira da Silva, F. (2016), "The mismatch among design education-researchpractice: how to strengthen the bridge?" The Design Principles and Practices Journal Collection, Vol. 11 No. 4, pp. 17-28. https://doi.org/10.18848/2325-128X/CGP/v11i04/17-28 
Dzib Goodin, A. (2012), Successful at the academy, less so at finding employment: different skills needed. [online] Available at: http://www.evolllution.com/curriculum_planning/successful-at-the-academy-less-so-at-findingemployment-different-skills-needed/

European Commission (2013), Report to the European Commission on Improving the quality of teaching and learning in Europe's higher education institutions, Luxembourg.

European Commission (n.d.) Descriptors defining levels in the European Qualifications Framework (EQF). [online] Available at: https://ec.europa.eu/ploteus/content/descriptors-page

Fullan, M. (2013), Great to excellent: Launching the next stage of Ontario's education agenda. [online] Ministry of Education, Toronto. Available at: www.edu.gov.on.ca./eng/document/reports/FullanReport_EN_07.pdf

Fullan, M. and Langsworthy, M. (2014), “A rich seam: How new pedagogies find deep learning”, Leadership and Policy in Schools, Vol. 15 No. 2, pp. 231-233. https://doi.org/10.1080/15700763.2015.1073331

Gabe, T.M. and Abel, J.R. (2012), "Specialized knowledge and the geographic concentration of occupations", Journal of Economic Geography, Vol.12 No. 2, pp. 435-453. https://doi.org/10.1093/jeg/lbr006

Gouveia, T. (2003), “A globalização como fenómeno de homogeneização cultural”, Globalização e democracia: os desafios do século XXI, Colibri, Lisboa, pp. 13-21.

Guthrie, J.W. (2009), "The case for a modern doctor of education degree (Ed. D): Multipurpose education doctorates no longer appropriated", Peabody Journal of Education, Vol. 84 No. 1, pp. 3-8. https://doi.org/10.1080/01619560802679526

Hattie, J. (2012) Visible Learning for teachers: Maximizing impact on learning, Routledge, London. https://doi.org/10.4324/9780203181522

Holtzman, D.M. and Kraft, M. (2011), "Skills needed in the 21st century workplace: A comparison of feedback from undergraduate business alumni and employers with a national study", Business Education \& Accreditation, Vol. 3 No. 1, pp. 61-76.

Jacquinot, G. (1993,) “Apprivoiser la distance et supprimer l'absence? Ou les défis de la formation à distance”, Revue Française de Pedagogie, Vol. 102 No. 1, pp. 55-67. https://doi.org/10.3406/rfp.1993.1305

Miles, J.J., Cairns, S. and Huston, M. (2002), Seven Habits of Successful Students, Counselling Centre, University of Calgary.

Pellegrino, J. and Hilton, M. (2012), Educating for life and work: Developing transferable knowledge and skills in the 21st century, National Research Council. https://doi.org/10.17226/13398

Tedesco, J.C. (2008), O novo pacto educativo: Educação, competitividade e cidadania na sociedade moderna, Vila Nova de Gaia, Fundação Manuel Leão.

Swanson, G. (1997), "Graphic Design Education as a Liberal Art: Design and Knowledge in the University and the "Real World"”, Design Issues, Vol. 10 No. 1, pp. 53-63. https://doi.org/10.2307/1511656

Prof. Rita Assoreira Almendra, Associate Professor with Aggregation Universidade de Lisboa, Faculdade de Arquitectura, CIAUD, Design Rua Sá Nogueira, Polo Universitário, Alto da Ajuda, 1349-055 Lisboa, Portugal Email: almendra@fa.ulisboa.pt 